Walker, Nathan ORCID:

https://orcid.org/0000-0001-8419-9018 (2017) Action Score Generator (2014). Journal of writing in creative practice, 9 (3). pp. 295-297.

Downloaded from: http://ray.yorksj.ac.uk/id/eprint/2465/

The version presented here may differ from the published version or version of record. If you intend to cite from the work you are advised to consult the publisher's version: https://www.intellectbooks.co.uk/journals/view-Journal,id=154/

Research at York St John (RaY) is an institutional repository. It supports the principles of open access by making the research outputs of the University available in digital form. Copyright of the items stored in RaY reside with the authors and/or other copyright owners. Users may access full text items free of charge, and may download a copy for private study or non-commercial research. For further reuse terms, see licence terms governing individual outputs. Institutional Repository Policy Statement

\title{
RaY
}

Research at the University of York St John

For more information please contact RaY at ray@yorksj.ac.uk 


\title{
Nathan Walker
}

York St John University

\section{Action Score Generator (2014)}

\begin{abstract}
The Action Score Generator is an online writing machine that writes and re-writes an infinite series of performance event scores. The source texts collect together previously performed actions by artist Nathan Walker between 2006 and 2013. The scores are arranged into poetic, six-word-length instructions, aligning performance objects, tasks, verbs and spaces that are reorganized endlessly by a JavaScript code. The Action Score Generator aligns itself with the short poetic texts of Fluxus Event Scores and with rhythms of computational data and visual poetry. An Action Score Generator book is published by IF P THEN Q Press, Manchester, including an Afterword by Mark Leahy entitled 'An action movie (for NW): Reading time code action'.
\end{abstract}


http://www.nathan-walker.co.uk/actionscoregenerator 


\section{Suggested citation}

Walker, N. (2017 [2016]), ‘Action Score Generator (2014)’, Journal of Writing in Creative Practice, 9:3, pp. 295-97, doi: 10.1386/jwcp.9.3.295_1

\section{Contributor details}

Nathan Walker is a performance artist and poet from Workington in West Cumbria. His work explores and constructs relationships between performance and writing. Based in York, he is co-founder of performance art organization Oui Performance with Victoria Gray, and teaches at York St John University. 